\title{
The Effect of Brand Image and Perception of Products on The Purchase Decisions of Matic Motorcycle in East Belitung
}

\author{
Ahmad Azmy ${ }^{1, *}$, Dery Nauyoman², Muhammad Zakky ${ }^{3}$ \\ ${ }^{1,2,3}$ School of Management \& Leadership, Tanri Abeng University \\ *Email: ahmadazmy@tau.ac.id
}

\begin{abstract}
This study aims to analyze the influence of brand image and product perception on automatic motorcycle purchasing decisions in East Belitung. Motorbikes are vehicles that are of interest to consumers with a number of factors that consider purchasing as needed. The object of this study analyzes how consumers consider a number of factors that function as motorcycle purchasing decisions. The research method uses regression analysis with a sample of 100 people. This research was conducted for three months from August to October 2018. The location of the study was East Belitung. The variables used are brand image and product perception as an independent variable, while purchasing decisions as the dependent variable. The statistical method used to test the data in this study is the method of multiple linear regression analysis. The results of this study are partially brand image has a significant influence on purchasing decisions, product perception has a significant influence on purchasing decisions. Simultaneously brand image and product perception have a joint influence on purchasing decisions. This study provides a recommendation that in improving consumer decisions one must consider how to promote brand image in proportion to product perception. These two things will always be a consideration of consumers in buying a product and brand strength is a top priority.
\end{abstract}

Keywords: Brand Image; Product Perception; Purchasing Decision; East Belitung; Regression Analysis

\section{Introduction}

Motorbikes are one of the modes of transportation that are high demand in Indonesia given the affordable price and the geographical conditions of Indonesia that make motorcycles able to reach remote areas. Congestion is a problem faced by big cities in Indonesia, especially the national capital, Jakarta, automotive companies see this problem as an opportunity to create new products to deal with this problem, Astra Honda Motor and Yamaha Indonesia Motor Manufacturing create a product motorcycle vehicles without using transmissions or commonly called automatic scooters. Along with the development of the company Astra Honda Motor and Yamaha Indonesia Motor Manufacturing, creating technology to reduce fuel use. Astra Honda Motor uses PGM-F1 technology, while Yamaha Indonesia Motor Manufacturing uses Blue Core technology to reduce fuel use on motorcycle vehicles. The selection of the location of East Belitung as a research object is due to the increasing infrastructure development and easy road access so that the use of motorbikes is an alternative for the community in carrying out both business \& social activities.
Astra Honda Motor and Yamaha Indonesia Motor Manufacturing each create automatic motorcycle products. Astra Honda Motor with Beat series products, Vario, and PCX, while Yamaha Indonesia Motor Manufacturing issues Mio series, Xeon Series and MAX series products. Each brand has its own brand slogan, for example Honda with "One Heart" and Yamaha with "Revs Your Heart". Kotler and Armstrong (2016) explained that a brand is a name, word, sign, symbol, or design or a combination of all that identifies the maker or seller of certain products and services. Indicator of brand image according to Low and Lamb (2000), among others: friendly/unfriendly: ease of recognition of consumers, modern/outdate: having models that are up to date/useful, not useful: can be used well/useful, popular/unpopular: familiar in the minds of consumers, gentle/harsh: has a fine product texture, artificial/natural: the authenticity of supporting components or shapes.

The geographical condition of East Belitung Regency which has a land area of $2,506.91 \mathrm{~km} 2$, which is divided into 7 (seven) sub-districts namely: Dendang, Gantung, Manggar, Kelapa Kampit, Renggiang Simpang, Simpak Pesak and 
Damar, and divided into 39 (thirty nine ) the village inside, with Manggar as the district capital. The distance between one city and around 2,743 units in 2015 in Belitung. The length of the district road in East Belitung in 2017 was in good condition $355.73 \mathrm{~km}$, in a

Table 1. East Belitung Population Data on 2017

\begin{tabular}{clccc}
\hline No & \multicolumn{1}{c}{ District } & $\begin{array}{c}\text { Width Area } \\
\left(\mathrm{km}^{2}\right)\end{array}$ & $\begin{array}{c}\text { Number of } \\
\text { Population }\end{array}$ & $\begin{array}{c}\text { Population department } \\
(\text { soul/km2) }\end{array}$ \\
\hline 1 & Manggar & 229 & 37.811 & 165,11 \\
\hline 2 & Gantung & 236,9 & 26.242 & 48,04 \\
\hline 3 & Dendang & 546,3 & 9.994 & 41,08 \\
\hline 4 & Kelapa Kampit & 362,2 & 18.016 & 36,14 \\
\hline 5 & Damar & 498,5 & 12.505 & 52,79 \\
\hline 6 & Simpang Renggiang & 390,7 & 7.070 & 18,10 \\
\hline 7 & Simpang Pesak & 243,3 & 8.169 & 22,55 \\
\hline & Total & $\mathbf{2 . 5 0 6 , 9}$ & $\mathbf{1 1 9 . 8 0 7}$ & $\mathbf{4 7 , 7 9}$ \\
\hline
\end{tabular}

Source: Database Kementerian Dalam Negeri Tahun 2017

another city is quite far and the mode of public transportation is not sufficient to carry out mobility from one region to another. The intercity bus operating hours are managed by the Department of Transportation only in the morning for departure and during the day for return, there are also cars that are rented out by private parties or private companies for mobility of the population but only during the morning and afternoon hours. This makes the residents there prefer to use motorbikes as the main means of transportation to travel both for daily activities and traveling far away.

Given the considerable distance traveled, people need a motorcycle that is comfortable to drive long distances, not only that the use of fuel is also expected to be reduced to a minimum and the motorbike has a fairly high speed. Matic motorbikes are one of the options to meet these needs considering that the wearer no longer needs to replace the transmission and is easy to use. The matic motorcycle company also creates a matic motorcycle with a large engine capacity ranging from $125 \mathrm{cc}$ to $250 \mathrm{cc}$, this makes the displacement distance between one city to another city in a shorter time. Based on data released from BPS in 2014, the number of families who own motorbikes in Bangka Belitung is around $72.58 \%$. Yamaha motorcycle sales in the January-July 2014 period were around 4,537 units, where motorbikes automatically dominated above $50 \%$. While sales of Honda motorcycles were moderate condition $19.84 \mathrm{~km}$, in a lightly damaged condition $21.14 \mathrm{~km}$, and the length of the district road in a damaged condition was $84.17 \mathrm{Km}$ with a total road length district/city $480.88 \mathrm{~km}$. The population in East Belitung can be seen in the Table 1 .

The table above represents the population in East Belitung based on subdistricts in East Belitung. It can be seen in the table that the Manggar sub-district has the largest population of 37,811 people, followed by the Gantung sub-district of 26,242 people, then Kelapa Kampit with a population of 18,016 people, Damar sub-district 12,505 people, Dendang sub-district 9,994 people, Simpang Pesak sub-district 8,169 people and finally sub-districts Simpang Rengiang as many as 7,070 inhabitants.

Motorcycle sales data released by the Indonesian Motorcycle Industry Association (AISI) in 2017 are as follows:

Table 2. Motorcycle Sales on 2017

\begin{tabular}{|c|c|c|}
\hline Type of Motor & Sales (Unit) & $\begin{array}{c}\text { Percentage } \\
(\%)\end{array}$ \\
\hline Skutik & 4.848 .540 & $82,37 \%$ \\
\hline Sport & 541.459 & $9,2 \%$ \\
\hline Cube/Bebek & 496.104 & $8,43 \%$. \\
\hline Total & 5.886 .103 & $100 \%$ \\
\hline $\begin{array}{ll}\text { ce: } & \text { AISI } \\
& \text { Moto }\end{array}$ & $\begin{array}{ll}\text { Asosiasi } & \text { In } \\
\text { donesia) }\end{array}$ & $\operatorname{tri} \mathrm{Se}$ \\
\hline
\end{tabular}

The table above shows sales of scootertype motorcycles successfully distributed 
sales of 4,848,540 units, followed by sport motorcycles 541,459 units and finally cub type or duck type with 496,104 units. In general, scooter type motorcycles control around $82.37 \%$ of the Indonesian domestic motorcycle market share in 2017 , followed by sport-type motorcycles at $9.2 \%$ and $8.43 \%$ duck type motorcycles. During 2017 there were a total of 5,886,103 motorcycle sales in Indonesia.

Astra Honda Motor's market share in 2017 was $74.51 \%$ while Yamaha Indonesia Manufacturing Motor was $22.90 \%$ and the rest by other companies. Based on the table above, it can be seen that the sales of Honda brand matic motorcycles were 3,612,647 units, while for the Yamaha brand there were $1,110,315$ units.

Consumer behavior in various places is very diverse, this is influenced by many supporting factors such as the presence of other consumers who influence consumers to buy products. According to Kotler (2000:176), the main factors that influence consumer purchasing behavior are cultural factors, social factors, personal factors and psychological factors. Cultural factors have the most extensive and profound influence on consumer behavior. Marketers must understand the role played by the buyer's culture, sub-culture, and social class. Personal factors that influence consumer purchasing decisions, among others, the age of the buyer, employment, economic conditions, and lifestyle. Social factors that influence a consumer's purchasing decision are the reference group, family and other consumer social status. Psychological factors are one of the factors that influence the behavior of all consumers, these factors include motivation, pre-emptive, knowledge and beliefs and attitudes.

Some studies explain brand image has a positive influence on purchasing decisions partially by $16.5 \%$, while the influence of product quality variables on purchasing decisions partially is $23.5 \%$ (Pratama and Apriatni, 2016). Zainudin (2010) explain that brand image and product perception have no influence on purchasing decisions. Therefore, this research proves the influence of brand image and perceived quality on the decision to purchase a motorcycle in East Belitung. The problems that will be studied are formulated, namely: brand image has a partial influence on purchasing decisions, product perceptions have a partial influence on purchasing decisions and product image and product perception have a simultaneous influence on purchasing decisions.

This study will analyze how brand image and product perception can influence consumer decisions in buying goods or services according to their needs \& preferences. Consumers will become more aware and understand in making purchasing decisions according to what is needed and what is offered by the product according to expectations. Product selection is focused on East Belitung because transportation which is an alternative is a two-wheeled vehicle or motorcycle. The focus of the research was narrowed down to motor matic so that the process of collecting data became easier and more effective. Therefore this research is expected to be able to perfect and strengthen how brand image and product perception become an alternative in consumer purchasing decisions.

\section{Theoretical Background}

\section{Brand Image}

Prasetya et al (2018) explained that a good brand image would be easily accepted by consumers over time to prove quality and meet buyer expectations. Brand is the company's ability to choose names, logos, symbols, design packages or attributes that are able to distinguish and identify products with competitors (Keller, 2013). The ability of a brand to influence purchasing decisions is determined by the time of proof of how the products purchased by consumers are able to meet the expectations and needs of buyers (Mamahit et al, 2015). Therefore, the brand must be built in accordance with the time period and what values must be trusted by the community as potential consumers.

Rangkuty (2002) explain brand image is a set of brand associations that are formed in the minds of consumers. Kotler \& Armstrong (2016) give definition of brand image is a 
number of beliefs about the brand. The view of the brand is a reflection of consumer memory of its association with the brand. Based on the opinion above can be concluded the notion of brand image is the result of the views or research of consumers towards a good or bad brand. This is based on consideration or selection by comparing the differences found in some brands, so that the brand whose offer is in accordance with the needs will be selected. A strong and positive image is one of the important things. Without a strong and positive image, it is very difficult for companies to attract new customers and retain existing ones. The right brand image of a product will certainly be very useful for consumers, because the brand image will affect consumer judgment on the alternative brands it faces.

Products are everything that can be offered to the market to satisfy wants and needs (Kotler \& Armstrong, 2016). Products offered to the market include physical goods, services, experiences, events, people, places, professions, ideas and organizations. Product quality according to Kotler and Armstrong (2016), is the ability of a product to carry out its functions including durability, reliability, accuracy, ease of operation and repair, and other valuable attributes. Based on the opinion above, it can be concluded that product perception is something that is felt by consumers after he consumes the value offered by the company, in which there are functions of a product including durability, reliability, accuracy, ease of operation and repair, and other valuable attributes. Purchasing decisions are one form of consumer behavior in using goods or services. Kotler \& Armstrong (2016) explain purchasing decisions are an act of consumers to form references among brands in the choice group and buy the most preferred products. Of the various factors that influence consumers in purchasing a product or service, usually consumers always consider the quality, price and products already known by the public.

Ruslim \& Tumewu (2015) dan Cahyani et al (2017) explain brand image variable has an influence on consumer purchasing decisions. Brand image is proven to have a significant and positive influence on consumer purchasing decisions on Pond's skin care products partially. Perceived Quality has a significant influence on Consumer Purchasing Decisions of Pond's skin care products. The perceived quality is proven to have a significant and positive influence on the desire of consumers to purchase Pond's skin care products partially. Novansa and Ali (2017) concluded that the brand image variable, brand awareness variable and price variable can simultaneously influence the purchasing decision variable significantly.

Dinawan (2010) explains that the factors that influence motorcycle purchasing decisions are product quality, price, and brand image. This is reinforced by Ariyono et al (2014) explaining that in buying a motorbike some consumers consider aspects of self-concept, personality, tastes, and experience. These factors are often used as a consideration of consumers in making motorbike purchasing decisions. Comparison of motorcycle brands between Honda and Yamaha has been decided in terms of consumer tastes and perspectives in evaluating the two brands. Brand image will always be a consideration of consumers coupled with experience and self-concept in the use of motorcycles as a means of transportation.

\section{Brand Image Relationship with Purchasing Decisions}

Fatmawati and Soliha (2017) explained that brand image will always be a consideration of consumers in buying a motorcycle. The brand will always be remembered by consumers where the product has succeeded in convincing both in terms of quality, price, and expectations can meet the value that can be given by the motor as a means of transportation and lifestyle. If the brand image of a product is known to consumers, consumers will not think about buying the product, plus if there is an emotional bond between the consumer and the brand. Previous research conducted by Tosan Widodo (2016), brand image has a positive effect on purchasing decisions. 
H1: Brand image has a partial influence on purchasing decisions

\section{Relationship between Product Perception and Purchasing Decision}

Yurita et al (2017) explains that consumer perceptions will influence the consideration of consumer purchasing decisions. This can be reflected in the aspects of price, quality, parts, and post-sale services offered by all brands to consumers. If the consumer has a perception of a product that the product is not good, it will affect consumers to buy the product. Pratama \& Apriatni (2016) product quality has a significant and positive effect on purchasing decisions. A product describes what is offered by the company and in it there are functions and attributes of the product itself.

H2 : Product perception has a partial effect on purchasing decisions

H3: Brand image and product perception have a simultaneous influence on purchasing decisions

Based on theoretical explanations the research model can be described as shown as Figure 2.

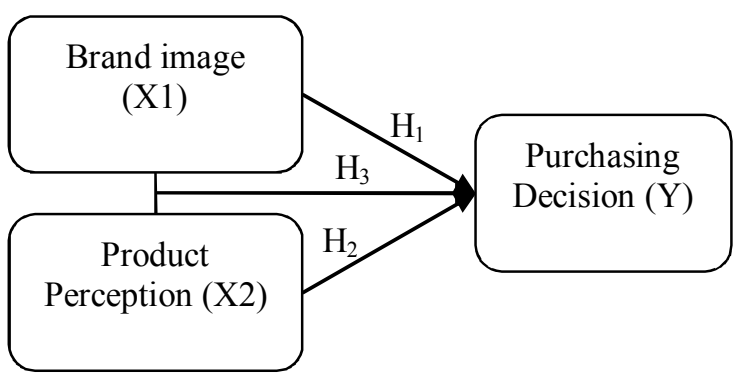

Figure 2. Research Framework

Sources: Fatmawati \& Soliha (2017), Tosan Widodo (2016), Yurita et al (2017, Pratama \& Apriatni (2016).

\section{Research Method}

\section{Population and Samples}

According to Sugiyono (2014) the population is a generalization consisting of objects/subjects that have certain quantity and characteristic activities determined by the researcher to be studied and conclusions drawn, while the sample is part of the number and characteristics possessed by the population. The population of this research was 119,807 people. Determination of the number of samples of this research using the Slovin formula. Slovin (1960), is a formula for calculating the minimum number of samples if the population behavior of the population is not known with certainty. Slovin formula as follows:

$$
n=\frac{N}{1+N\left(e^{2}\right)}
$$

Information :

$\mathrm{n}=$ sample size

$\mathrm{N}=$ Total population

$\mathrm{e}=$ Margin of error, maximum error rate is $10 \%$

$$
\begin{aligned}
n & =\frac{119.807}{1+119.807(10)^{2}}=\frac{119.807}{1+119.807(0,1)^{2}} \\
& =\frac{119.807}{1+1.198,07}=99.9 \text { rounded to } 100
\end{aligned}
$$

Based on the above formula, the researchers decided to take a total sample of 100 people.

\section{Data Collection}

The method of data collection in this research is to use the questionnaire method. Sugiyono (2014) explain the questionnaire is an instrument for collecting data, where participants or respondents fill in questions or statements given by researchers. The distribution of the research questionnaire was conducted in August, starting from August 1 to August 21.

\section{Analysis}

The data analysis method used in this research is to use the method of multiple linear regression analysis. In multiple linear regression there are several free variabeel (X1), (X2) and (Xn) that affect the dependent variable $(Y)$ with the aim of knowing the magnitude of the influence of the 
independent variables on the dependent variable. In multiple regression tests all independent variables are included in the regression calculation together. Research uses several tests to find out the valid/invalid question, reliable/unreliable a question, also a test to determine the effect of independent variables on the dependent variable partially or independent variables simultaneously.

\section{Results and Discussion}

\section{Profile of Respondents}

The composition of respondents by sex is $39 \%$ male and $61 \%$ female. Age of respondents is $18 \%$ aged $17-20$ years, $61 \%$ aged $21-30$ years, $19 \%$ aged $31-40$ years and $2 \%$ aged 41 years and above. The composition of respondents based on the respondent's work there were $61 \%$ of students, $3 \%$ of employees (public/private), $1 \%$ of self-employed, $18 \%$ of housewives, and $17 \%$ of other jobs not mentioned. Based on motorcycle brands owned there were 33\% of respondents who owned Honda brand automatic motorbikes and $67 \%$ of respondents had Yamaha motorbikes.

Table 3. Profile of Respondents

\begin{tabular}{llc}
\hline $\begin{array}{c}\text { Demographic } \\
\text { characteristics }\end{array}$ & \multicolumn{1}{c}{ Group } & $\begin{array}{c}\text { Frequency } \\
(\mathbf{\%})\end{array}$ \\
\hline Gender & Men & 39 \\
\hline Age & Women & 61 \\
\hline & 17-20 years & 18 \\
\hline & 21-30 years & 61 \\
\hline $\begin{array}{l}\text { 31-40 years } \\
\text { old }\end{array}$ & 19 \\
\hline 41 years and & 2 \\
\hline & above & 61 \\
\hline & Student & 3 \\
\hline & Employe & 1 \\
\hline Brand & Entrepreneur & 18 \\
\hline & Housewife & 17 \\
\hline & Other work & 33 \\
\hline & Honda & 67 \\
\hline
\end{tabular}

\section{Reliability Analysis}

Reliability test is a test used to measure the extent to which the measurement of a test remains consistent after more than one time on the same subject and condition. The results of the data analysis were compared $r$ count with the r-table value at a significant level of $5 \%$ and $\mathrm{db}=\mathrm{N}-2$ or with $120-2=$ 118. All independent variables (brand image and perceived quality). As seen in table 4, that $\mathrm{r}$ count $>\mathrm{r}$ table $(0.196)$, it can be concluded that all of these variables are reliable.

Table 4. Reliability Test Result

\begin{tabular}{llccc}
\hline Variable & Indicator & $\begin{array}{c}\mathbf{R} \\
\text { Test }\end{array}$ & $\begin{array}{c}\mathbf{R} \\
\text { Table }\end{array}$ & Note \\
\hline $\begin{array}{l}\text { Brand } \\
\text { Image }\end{array}$ & $\begin{array}{l}\text { Coorporate } \\
\text { Image (X1.1) }\end{array}$ &, 702 &, 196 & Reliabel \\
& $\begin{array}{l}\text { Product } \\
\text { Image (X1.2) }\end{array}$ &, 702 &, 196 & Reliabel \\
\hline $\begin{array}{l}\text { Product } \\
\text { Perception }\end{array}$ & $\begin{array}{l}\text { Design } \\
\text { (X2.1) }\end{array}$ &, 885 &, 196 & Reliabel \\
& $\begin{array}{l}\text { Technology } \\
\text { (X2.2) }\end{array}$ &, 885 &, 196 & Reliabel \\
& $\begin{array}{l}\text { Durability } \\
\text { (X2.3) }\end{array}$ &, 885 &, 196 & Reliabel \\
& & & & \\
\hline
\end{tabular}

\section{Validity Test}

The process of measuring the validity test by connecting or correlating the factor scores (the sum of all items in one factor) with the total score (total overall factor) of all items that exist. The results of the validity test on each question that has been tested using SPSS at a significant level of 0.05 , it can be seen that all the questions in the research questionnaire have a value of $r$ count $>\mathrm{r}$ table, then all questions regarding analysis as shown in table 5 are declared valid.

Table 5. Test for Validity Result

\begin{tabular}{llccc}
\hline Variable & \multicolumn{1}{c}{ Indicator } & $\begin{array}{c}\text { R } \\
\text { Test }\end{array}$ & $\begin{array}{c}\text { R } \\
\text { Table }\end{array}$ & Note \\
\hline $\begin{array}{l}\text { Brand } \\
\text { Image }\end{array}$ & $\begin{array}{l}\text { Coorporate } \\
\text { Image (X1.1) }\end{array}$ &, 856 &, 196 & Valid \\
& $\begin{array}{l}\text { Product Image } \\
\text { (X1.2) }\end{array}$ &, 902 &, 196 & Valid \\
Product & $\begin{array}{l}\text { Design (X2.1) } \\
\text { Perception }\end{array}$ &, 907 &, 196 & Valid \\
& $\begin{array}{l}\text { Technology } \\
\text { (X2.2) }\end{array}$ &, 904 &, 196 & Valid \\
& $\begin{array}{l}\text { Durability } \\
\text { (X2.3) }\end{array}$ &, 894 &, 196 & Valid \\
& & & & \\
\hline
\end{tabular}

\section{Determination Coefficient $\left(R^{2}\right)$}

The test is terminated as $r^{2}$. The value of determination coefficient is expressed in the square of the value of the correlation coefficient $r^{2} \times 100 \%=n \%$, meaning that the 
value of the dependent variable can be explained by the independent variable $\mathrm{n} \%$, while the remainder of $(100-n)$ is explained by other variables.

Table 6. Determination Coefficient $\left(\mathbf{R}^{2}\right)$ Result

\begin{tabular}{lcccc}
\hline Model & $\mathbf{R}$ & $\begin{array}{c}\mathbf{R} \\
\text { Square }\end{array}$ & $\begin{array}{c}\text { Adj. } \mathbf{R} \\
\text { Square }\end{array}$ & SE \\
\hline 1 &, $796^{\text {a }}$ &, 633 &, 626 &, 23091
\end{tabular}

a. Predictors: (Constant), Produt_perception, Brand_image

Based on the table above it is known that Adjusted R-Square is equal to, 626, meaning that the influence of independent variables (brand image and perceived quality) is $62.6 \%$ on the purchasing decision variable while $37.4 \%$ is influenced by variables not means that brand image variables and product perceptions have an influence on purchasing motorbike decisions. Novansa and Ali (2017), that the brand image variable, brand awareness variable and price variable can simultaneously influence the purchasing decision variable significantly. Amron (2018) explain that brand image, brand trust, product quality and price in this study collectively have a significant influence on the purchasing decision variable. So it can be concluded that quality, brand image, and service quality has a significant influence on consumer trust.

\section{Multiple Linear Regression Analysis}

Hypothesis testing is done by using multiple linear regression analysis to facilitate data analysis. All data processing is done using the SPSS program.

Tabel 7. F-test Result

\begin{tabular}{|c|c|c|c|c|c|c|}
\hline \multicolumn{2}{|c|}{ Model } & \multirow{2}{*}{$\begin{array}{r}\text { Sum of Squares } \\
8,938 \\
\end{array}$} & \multirow{2}{*}{$\begin{array}{r}\text { Df } \\
2 \\
\end{array}$} & \multirow{2}{*}{$\begin{array}{r}\text { Mean Square } \\
4,469 \\
\end{array}$} & \multirow{2}{*}{$\begin{array}{c}\mathbf{F} \\
83,813 \\
\end{array}$} & \multirow{2}{*}{$\frac{\text { Sig. }}{0,000^{6}}$} \\
\hline 1 & Regression & & & & & \\
\hline & Residual & 5,172 & 97 & 0,053 & & \\
\hline & Total & 14,110 & 99 & & & \\
\hline
\end{tabular}

a. Dependent Variable: purchase decision

b. Predictors: (Constant), Produt_perception, Brand_image

examined.

F-test

Based on the table above, the regression equation model can be obtained as follows:

According to Ghozali (2012), the F test basically shows that all independent variables have a joint influence on the dependent variable.

Based on the table above, the calculated $F$ value is 83,813 with a Sig value of 000. This shows that the value of FStatistic > F-Table 3.09 and the value of sig is smaller than 0.05 . Thus it can be concluded that Ho is rejected and $\mathrm{Ha}$ is accepted. This

$$
\begin{aligned}
& Y=a+b 1 x 1+b 2 x 2 \\
& Y=0.228+, 227 x_{1}+, 163 x_{2}
\end{aligned}
$$

Based on the above formulation, we can know the formulation of multiple linear regression to test the effect of independent variables (brand image and product perception) on the dependent variable (purchasing decision).

\begin{tabular}{|c|c|c|c|c|c|c|}
\hline \multirow{2}{*}{\multicolumn{2}{|c|}{ Model }} & \multicolumn{2}{|c|}{$\begin{array}{c}\text { Unstandardized } \\
\text { Coefficients }\end{array}$} & \multirow{2}{*}{$\begin{array}{c}\begin{array}{c}\text { Standardized } \\
\text { Coefficients }\end{array} \\
\text { Beta } \\
\end{array}$} & \multirow[t]{2}{*}{$\mathbf{T}$} & \multirow[t]{2}{*}{ Sig. } \\
\hline & & B & Std. Error & & & \\
\hline \multirow[t]{3}{*}{1} & (Constant) & 0,228 & 0,307 & & 0,744 & 0,459 \\
\hline & Brand image & 0,227 & 0,049 & 0,430 & 4,641 & 0,000 \\
\hline & Perception_product & 0,163 & 0,036 & 0,422 & 4,554 & 0,000 \\
\hline
\end{tabular}

Table 8. Multiple Linear Regression Analysis Result

a. Dependent Variable: purchase decision 
Constant (a) of 0.228 , meaning that if the brand image and perception of the product does not exist or the value is 0 (zero), then the purchase decision on automatic motorbikes in East Belitung is 0.228.

The above model explains that Brand Image (X1) can increase the percentage of purchasing decisions by $22.7 \%$. (0.227). It can be concluded that there is a positive relationship between brand image and the decision to buy a motorcycle by consumers. All are considered constant and there is no change in considering the brand image of the motor by consumers.

Based on the above model that the perception of the product is able to increase the purchasing decision of motor consumers by $1.3 \%(0.163)$. This explains the positive relationship between product perceptions of motorcycle consumer purchasing decisions in East Belitung. All indicators are considered constant and increase or decrease outside the research model. Therefore, the positive relationship between product perception can improve the purchasing decisions of motor consumers in East Belitung.

Based on the explanation above, the relationship between perceived quality and greater purchasing decisions is 0.227 or $22.7 \%$ rather than the influence of brand image on purchasing decisions which is equal to 0.163 or $16.3 \%$. Ruslim \& Tumewu (2015) and Novansa \& Ali (2017) explain that brand image has a positive effect on purchasing decisions. Cahyani et al (2017) conclude that perception of product witn quality indicator has a positive impact on purchasing decisions.

\section{T-test}

According to Ghozali (2012), a different test $\mathrm{t}$-test is used to test how far the influence of the independent variables used in this research is idividual in explaining the dependent variable partially. The results of the research for the $T$ Test can be seen in Table 9.

Based on table 9 and the known ttable value, it can be determined how much influence the independent variable on the dependent variable individually. The influence of the independent variables on the dependent variable can be seen in the description below:

1. The influence of brand image on the decision to purchase automatic motorbikes in East Belitung.

Based on table 9, it can be obtained a T-Statistic of 4,641 and a sign value of 000 . This shows that the T-Statistic $>\mathrm{T}$ table which is 1.660 and the sig value $<$ 0.05 . Based on these comparisons, the initial hypothesis which states that brand image has an influence on acceptable purchasing decisions. This means that brand image variables have a significant influence on the dependent variable (purchasing decision). Hulu et al (2018) explain that brand image and intention to buy has not relationship on purchasing decision. Ping Li (2016) strengthen that brand image has not implication on purchasing decision. Amron (2018) and Novanza \& Ali (2017) strengthen the research result that brand image has relationship on purchasing decision.

Brand image will have implications for consumers in considering several factors in making purchasing decisions. Wulandari \& Oktafani (2017) and Supriyadi et al (2016) explained that brand image has a high enough probability to improve the purchasing decision making process by consumers.

Table 9. T-test Result

\begin{tabular}{|c|c|c|c|c|c|c|}
\hline \multicolumn{2}{|c|}{ Model } & \multicolumn{2}{|c|}{$\begin{array}{l}\text { Unstandardized } \\
\text { Coefficients }\end{array}$} & \multirow{2}{*}{$\begin{array}{c}\begin{array}{c}\text { Standardized } \\
\text { Coefficients }\end{array} \\
\text { Beta }\end{array}$} & \multirow[t]{2}{*}{$\mathbf{T}$} & \multirow[t]{2}{*}{ Sig. } \\
\hline & & B & Std. Error & & & \\
\hline \multirow[t]{3}{*}{1} & (Constant) & 0,228 & 0,307 & & 0,744 & 0,459 \\
\hline & Brand image & 0,227 & 0,049 & 0,430 & 4,641 & 0,000 \\
\hline & Perception product & 0,163 & 0,036 & 0,422 & 4,554 & 0,000 \\
\hline
\end{tabular}

a. Dependent Variable: purchase decision 
The product purchased will be considered whether the brand purchased is able to meet consumer expectations in purchasing a motorcycle. Motorcycle products purchased must meet consumer expectations in meeting their needs. Cahyani \& Sutrasmawati (2016) explained that the brandi image would be able to create consumer loyalty towards motorcycle purchasing decisions. Every purchase process will always be considered several components and one of them is a brand image that is inherent in the minds of consumers. Therefore, companies must be able to improve their brand image in the eyes of consumers and the products sold must be able to meet both short \& long term expectations.

2. Effect of product perceptions on purchasing decisions for motorbikes in East Belitung

Based on table 9 can be obtained TStatistic of 4.554 and sig value of .000 . This shows the value of T-statistic $>\mathrm{t}$ table (1.660) and the value of sig $<0.05$. From these comparisons, the initial hypothesis states that the product perception variable influences the accepted purchasing decision. This means that purchasing decision variables have a significant effect on the dependent variable (purchasing decision). Amron (2018) explain product perception has significant effect on consumer purchasing decision. Product perception will be a consideration of consumers in buying a motorcycle. The family and the closest person will be asked for opinion on how the motorbike product to be purchased is of good quality and spare parts are available in the market. Yoesmanam (2018) explains that product perception has an influence on consumer purchasing decisions. Product perception will always be identified with the quality and comfort of the motorcycles that will be purchased by consumers. Product quality will always be considered by consumers so that the purchasing decision process is in accordance with the needs and availability of the company.

\section{Conclusion and Recomendation}

\section{Conclusion}

Based on the results of research that has been done on brand image variables, it was found that the brand image variable has a significant influence on the purchase of matic motorcycles, brand recognition carried out by each company has been embedded in the minds of consumers that one of the matic motorcycles has advantages in In terms of fuel and other brands it has advantages in speed. The results of the research that has been done on the product perception variable, the results show that the product perception variable has a significant influence on the purchase of motorbikes. Based on the description above can be concluded from the two independent variables, namely brand image and product perception have a significant influence on the purchase decision of a motorcycle. There are influences of other variables not examined, this can be seen in table 6, the Adjusted R-square value is obtained, 626 or $62.6 \%$ for the variables studied while the remaining $37.4 \%$ are other variables not examined.

\section{Recomendation}

Independent variables that influence the purchase decision of a motorcycle, can be used as an evaluation for automotive companies that there are changes in the behavior of consumers who initially use motorbikes that have transmissions are now turning to motorbike matic. This was also influenced by changes in motorcycle technology during the millennium, where initially consumers only bought motorbikes just for their needs, now becoming a lifestyle. Millennial consumers have also understood that the 
use of motorbikes not only affects the consumers/users of motorcycles themselves but also the increasingly changing environment. Continuous technology implementation and up-todate technology will make motorbikes that companies create have the advantage of competitors, not only that technology changes that must be faster can be followed by motorized companies to make the company able to survive in market competition. The application of new technologies such as the injection and Blue core technology applied by Yamaha is expected to be able to change the image of Yamaha products which initially require more fuel can now be more economical. The intense competition between automotive companies has resulted in companies having to look at every opportunity that exists, product improvement from year to year can be expected to increase the influence of consumer decisions to make purchases. Product improvements will change the brand image along with technological changes that are applied to automatic motorbikes and reduce the failure of products on the market. The application of new technology will change the image of the product from less good to better, for example injection technology that uses carburetor technology will save fuel use on motorbikes, this will change the mindset of consumers who initially said Yamaha brand matic motorbikes are not fuel efficient to be fuel efficient because of technological changes.

\section{Daftar Referensi}

Amron, A. (2018). Effects Of Product Quality, Price, And Brand Image On The Buying Decision Of City Car Product. Archives of Business Research, 6(4).

Amron.(2018).The Influence of Brand Image, Brand Trust, Product Quality, and Price on the Consumer's Buying Decision of MPV Cars. European Scientific Journal. Vol.14, No.13

Ariyono, K. B., Meitriana, M. A., \& Zukhri, A. (2014). Analisis FaktorFaktor Yang Mempengaruhi Keputusan Pembelian Sepeda Motor Matic Honda Pada Dealer Astra Motor Denpasar. Jurnal Pendidikan Ekonomi Undiksha, 4(1).

Cahyani, N. S., Lapian, S. L., \& Tumiwa, J. (2017). The Effect of Brand Image, Perceived Price, \& Perceived Quality on Consumers Purchase Decision of Pond's Skin Care Product. Jurnal EMBA: Jurnal Riset Ekonomi, Manajemen, Bisnis dan Akuntansi, 5(2).

Cheng-Ping, L. D. (2017). Effects of Brand Image, Perceived Price, Perceived Quality, and Perceived Value on The Purchase Intention Towards Sports and Tourism Products of The 2016 Taichung International Travel Fair. Journal of International Management Studies, 12(2), 97-107.

Dinawan, M. R. (2010). Analisis FaktorFaktor Yang Mempengaruhi Keputusan Pembelian (Studi Kasus Pada Konsumen Yamaha Mio Pt Harpindo Jaya Semarang). Doctoral dissertation. Semarang: Universitas Diponegoro).

Fatmawati, N., \& Soliha, E. (2017). Kualitas Produk, Citra Merek dan Persepsi Harga Terhadap Proses Keputusan Pembelian Konsumen Sepeda Motor Matic "Honda". Jurnal Manajemen Teori dan Terapan| Journal of Theory and Applied Management, 10(1), 1-20.

Ghozali, Imam.(2012). Aplikasi Analisis Multivariate dengan Program IBM SPSS 20. Semarang: UNDIP. 
Hulu, Paulinus. Ruswanti, Endang. Hapsari, N. Puspita (2018). Influence of Product Quality, Promotion, Brand Image, Consumer Trust towards Purchase Intention (Study Case on Pocari Sweat Isotonic Drink). Journal of Business and Management (IOSR-JBM), Volume 20, Issue 8. Ver. I (August. 2018), PP 55-61.

Keller, Kevin L. 2013. Strategic Brand Management; Building, Measuring, and Managing Brand Equity. Fourth Edition Harlow. English: Pearson Education Inc.

Kotler, Philip \& Amstrong, Gary. (2016). Prinsip-prinsip Pemasaran. Edisi 13. Jilid 1. Jakarta: Erlangga.

Low, G. S., \& Lamb Jr, C. W. (2000). The Measurement and Dimensionality of Brand Associations. Journal of Product \& Brand Management, 9(6), 350-370.

Mamahit, P. (2015). Pengaruh Brand Image, Brand Trust, dan Kualitas Produk Terhadap Keputusan Pembelian Mobil Toyota All New Yaris Pada PT. Hasjrat Abadi Manado. Jurnal Berkala Ilmiah Efisiensi, 15(5).

Novansa, H., \& Ali, H. (2017). Purchase Decision Model: Analysis of Brand Image, Brand Awareness and Price (Case Study SMECO Indonesia SME products). Saudi Journal of Humanities and Social Sciences, ISSN, 2415-6256.

Pratama, D., \& Apriatni, E. P. (2016). Pengaruh Citra Merek Dan Kualitas Produk Terhadap Keputusan Pembelian Sepeda Motor Yamaha Mio J (Studi Kasus Pada PT Yamaha Bahana Tegal). Jurnal Ilmu Administrasi Bisnis, 5(4), 272-289.

Prasetya, E. G., Yulianto, E., \& Sunarti, S. (2018). Pengaruh Brand Image
Terhadap Keputusan Pembelian (Survei Pada mahasiswa Fakultas Ilmu Administrasi Bisnis Progam Studi Administrasi Bisnis angkatan 2014 konsumen Air Mineral Aqua). Jurnal Administrasi Bisnis, 62(2), 214-221.

Rangkuty, Freddy.(2002). The Power of Brand,Teknik Mengelola Brand Equity dan Strategy Perluasan Merek. Jakarta: Gramedia.

Ruslim, A. C., \& Tumewu, F. J. (2015). The Influence of Advertisement, Perceived Price, and Brand Image on Consumer Buying decision to Asus Mobile Phone. Jurnal EMBA: Jurnal Riset Ekonomi, Manajemen, Bisnis dan Akuntansi, 3(3).

Sugiyono. (2014). Metode Penelitian Pendidikan Pendekatan Kuantitatif, Kualitatif Dan $R \& D$. Bandung: Alfabeta.

Supriyadi, S., Wiyani, W., \& Nugraha, G. I. K. (2017). Pengaruh Kualitas Produk dan Brand Image Terhadap Keputusan Pembelian. Jurnal bisnis dan manajemen, 4(1).

Cahyani, K.I. Sutrasmawati, R. E. (2016). Pengaruh Brand Awareness dan Brand Image Terhadap Keputusan Pembelian. Management Analysis Journal, 5(4).

Widodo, T. (2016). Pengaruh Brand Image, Atribut Produk, dan Harga Terhadap Keputusan Pembelian Sepeda Motor Honda Vario di Kulon Progo. Skripsi. Yogyakarta: Universitas Negeri Yogyakarta.

Wulandari, D. A., \& Oktafani, F. (2017). Pengaruh Brand Image Terhadap Proses Keputusan Pembelian Sepatu Nike (Studi Pada Mahasiswa Fakultas Komunikasi dan Bisnis Telkom University Bandung). Jurnal Computech \& Bisnis, 11(1), 47-58. 
Yurita, A., \& Makmur, A. A. (2017). Analisis Pengaruh Persepsi Konsumen Terhadap Keputusan Pembelian Sepeda Motor Honda Matic Di Dealer Prima Motor Pasir pengaraian. Jurnal Mahasiswa Prodi Manajemen Fakultas Ekonomi, 4(1).

Yoesmanam, I. C. (2018). Pengaruh Pengetahuan Produk dan Persepsi Kualitas Produk terhadap Keputusan Pembelian pada Kosmetik Organik.
BISMA (Bisnis dan Manajemen), 7(2), 134-142.

Zainuddin, Didi. (2010). Analisis Pengaruh Promosi, Kualitas Produk, dan Brand Image Motor Matic Honda Terhadap Keputusan Pembelian Serta Dampaknya Terhadap Loyalitas Pelanggan (Study Kasus Pengguna Sepeda Motor Matic di Ciputat Timur Tanggerang Selatan). Jakarta: UIN Syarif Hidayatullah. 